\title{
Die betekenis van ritueelteorie vir rousmartpastoraat
}

\begin{tabular}{|c|c|}
\hline \multicolumn{2}{|c|}{$\begin{array}{l}\text { Authors: } \\
\text { Santie Bothe-Smith }{ }^{1} \\
\text { Yolanda Dreyer }{ }^{1}\end{array}$} \\
\hline \multicolumn{2}{|c|}{$\begin{array}{l}\text { Affiliations: } \\
{ }^{1} \text { Department of Practical } \\
\text { Theology, University of } \\
\text { Pretoria, South Africa }\end{array}$} \\
\hline \multicolumn{2}{|c|}{$\begin{array}{l}\text { Note: } \\
\text { This article is based on the } \\
\text { research of Santie Bothe- } \\
\text { Smith's PhD dissertation, } \\
\text { entitled 'Rousmart en } \\
\text { ritueel: 'n Pastorale } \\
\text { perspektief' done under } \\
\text { the supervision of Prof. Dr } \\
\text { Yolanda Dreyer, Department } \\
\text { of Practical Theology, Faculty } \\
\text { of Theology, University of } \\
\text { Pretoria (2014). }\end{array}$} \\
\hline \multicolumn{2}{|c|}{$\begin{array}{l}\text { Correspondence to: } \\
\text { Santie Bothe-Smith }\end{array}$} \\
\hline \multicolumn{2}{|c|}{$\begin{array}{l}\text { Email: } \\
\text { santie@jasonsmith.co.za }\end{array}$} \\
\hline \multicolumn{2}{|c|}{$\begin{array}{l}\text { Postal address: } \\
708 \text { Biotite Street, Elardus } \\
\text { Park 0181, South Africa }\end{array}$} \\
\hline \multicolumn{2}{|c|}{$\begin{array}{l}\text { Dates: } \\
\text { Received: } 19 \text { June } 2014 \\
\text { Accepted: } 26 \text { July } 2014 \\
\text { Published: } 20 \text { Nov. } 2014\end{array}$} \\
\hline \multicolumn{2}{|c|}{$\begin{array}{l}\text { How to cite this article: } \\
\text { Bothe-Smith, S. \& Dreyer, } \\
\text { Y., 2014, 'Die betekenis } \\
\text { van ritueelteorie vir } \\
\text { rousmartpastoraat', } \\
\text { HTS Teologiese Studies/ } \\
\text { Theological Studies 70(3), } \\
\text { Art. \#2770, } 10 \text { pages. http:// } \\
\text { dx.doi.org/10.4102/hts. } \\
\text { v70i3.2770 }\end{array}$} \\
\hline \multicolumn{2}{|c|}{$\begin{array}{l}\text { Copyright: } \\
\text { (C) 2014. The Authors. } \\
\text { Licensee: AOSIS } \\
\text { OpenJournals. This work } \\
\text { is licensed under the } \\
\text { Creative Commons } \\
\text { Attribution License. }\end{array}$} \\
\hline \multicolumn{2}{|l|}{ Read online: } \\
\hline 口irip & $\begin{array}{l}\text { Scan this QR } \\
\text { code with your } \\
\text { smart phone or } \\
\text { mobile device } \\
\text { to read online. }\end{array}$ \\
\hline
\end{tabular}

The value of ritual theory for pastoral care in times of grief. In this article the focus is on ritual theory and its relevance for pastoral care during the grief process. For these purposes the first task at hand is finding an appropriate description of what ritual implies, especially in the context of pastoral care. It includes studying different descriptions from different study fields to provide a broad theoretical view of ritual and to identify relevant perspectives. This view is narrowed to ritual as performance as well as legitimisation of experience. Concerning the pastoral aspect of grief care the research mainly focuses on the work of the Dutch practical theologian, Corja Menken-Bekius and the American practical theologian David Hogue. Menken-Bekius' works on ritual from a clinical pastoral perspective while Hogue gives a neuropsychological perspective. Included in the processing of these two views are the works of anthropologist, Roy Rappaport and psychologist, Onno Van der Hart. Finding a description of ritual is not an easy task. The one offered is created with careful consideration of the inclusions and exclusions within the 'idea' of ritual. Meaning is subjective when it comes to ritual. A general meaning might be ascribed to a specific ritual, yet each individual might have a different experience and might attach different meanings. This happens unwittingly and unwillingly. What is found to be important in the rituals proposed in this article, is the ability of rituals to provide a framework of order within a situation of chaos and that it also creates a moment of remembrance.

\section{Ritueel as menslike fenomeen}

Die artikel fokus op ritueel-teorie in pastoraat en die relevansie daarvan vir die rouproses. Die insigte van die antropoloog, Roy Rappaport ([1968] 1980, 1999), die psigoloog, Onno Van der Hart (1983; 1990) en die praktiese teoloë David Hogue (2003) en Corja Menken-Bekius (1998, 2001, 2007) het bygedra tot die ontwikkeling van 'n selfstandige perspektief.

Ritueel kan as 'n universeel menslike neiging tot dramatisering beskryf word. Resente ontwikkelinge met betrekking tot die evaluasie van rituele is uiteenlopend. Daar is dié wat meen dat die mens ' $n$ behoefte aan rituele het, terwyl ander die afskud van die sosiale en ideologiese beperkinge van ritualisme as vooruitgang beskou (kyk Bell 1997:172). Daar is dié wat dit positief waardeer en ander wat vrees dat rituele besig is om uit te sterf. Daar is dié wat meen dat nuwe kreatiewe uitdrukkingsvorme van rituele ontwikkel, sodanig so dat selfs in vreemde tradisies na nuwe moontlikhede ondersoek ingestel word. Hoewel 'n omskrywing van die term ritueel met die nodige versigtigheid benader behoort te word, meen Geertz (1975) dat dit wel nut kan hê:

Although it is notorious that definitions establish nothing, in themselves they do, if they are carefully enough constructed, provide a useful orientation, or reorientation of thought, such that an extended unpacking of them can be an effective way of developing and controlling a novel line of inquiry. (bl. 90)

Hoe ritueel verstaan word, het met verloop van tyd verander. In Die Handwoordeboek van die Afrikaanse taal (1972) word ritueel beskryf as 'n kultiese handeling, naamlik 'n ritus of ritueel, 'n godsdienstige, simboliese handeling waarmee kontak tussen die menslike en goddelike bewerkstellig word. Dit sluit geloofseremonies in. In die alledaagse taalgebruik het die begrip 'n breër betekenis gekry. Gesprekke oor die drakrag van die begrip 'ritueel' word al lank in die wetenskaplike wêreld gevoer. Volgens Zuesse (1987:405), Platvoet (1995:25) en Leach (1968:526) is 'n beskrywing van ritueel nie' $n$ eenvoudige saak nie. Die oorgrote meerderheid studies oor ritueel word op die terrein van die antropologie gedoen, terwyl hierdie term in die godsdienswetenskap nog nie voldoende ontgin is nie.

Pogings om 'ritueel' te beskryf word deur beperkings gestuit. Word dit te sterk afgegrens, val handelinge wat wel tersake is, uit. Word die grense nie duidelik genoeg gestel nie, vervaag die betekenis van die begrip. Indien rituele handelinge geëvalueer sou word, sou aangeleerde gedrag en gewoontes heel onder op die skaal wees, terwyl liturgiese en seremonieel-komplekse, simboliese 
handelinge heel bo sou wees (kyk Menken-Bekius 1998:22). Tussen hierdie twee pole kan 'n legio ander moontlikhede geïdentifiseer word. Volgens Crossley (2004:32) beskik rituele oor 'familietrekke eerder as 'n vasgestelde en duidelike essensie'. Dit sou dus 'onverstandig wees om ritueel eng te definieer'. Daar behoort egter ook nie gepoog te word om die term 'ritueel' so wyd te definieer dat dit op alle gevalle van toepassing kan wees nie. Daarvoor is die betekenis, funksie en kenmerke van die rituele van verskillende instansies te verskillend. Ten spyte van die beperkings word die term 'ritueel' tog nog wyd gebruik. Dit is nie altyd moontlik om 'n rituele handeling van alledaagse aktiwiteite te onderskei nie. Die vraag wat gevra moet word, is of dit iets in die handeling self is wat dit 'n 'ritueel' maak en of dit die intensie van die mense, wat die aksie uitvoer, is wat dit ' $n$ 'ritueel' maak.

'n Ritueel is 'n manier van kommunikeer. Om as 'ritueel' gekwalifiseer te word, moet daar' $n$ handeling wees. Daar moet mense wees wat dit uitvoer en daar moet ' $n$ 'gehoor' wees wat die handeling interpreteer. ' $n$ Religieuse sisteem is nie aan ritueel gelyk nie. ' $n$ Ritueel is 'n uitvoerende onderdeel van 'n godsdienssisteem (Lewis 1980:9-10). Sørensen (2007:282-283) is dit met Lewis eens dat rituele iets van die bo-natuurlike en ook spesifiek sosiale handelinge uitdruk - handelinge wat in die teenwoordigheid van ander uitgevoer word óf wat saam met ander uitgevoer word. Rituele word nie net uitgevoer nie, dit word ook waargeneem (Sørensen 2007:282-283). Vir die fokus van hierdie artikel is ' $n$ spesifieke gehoor nie ter sake nie, omdat ' $n$ ritueel hier as 'n hoogs intieme en persoonlike aangeleentheid beskou word.

Vervolgens word 'n versigtige beskrywing van die term ritueel gebied om, soos Van Strien (1986:55) dit verwoord, as 'n heuristiese soeklig te dien. Dit bied 'n wyse waarop mense prakties en interaktief by die ontdekking van betekenis in eie konteks en volgens eie behoeftes betrokke kan wees. Selfs buitestaanders wat nie noodwendig aan die spesifieke ritueel deelneem nie, kan, in die rol van waarnemers met eie konteks en behoeftes, tog bydra tot die betekenis van die ritueel. Ritueel is dus vloeibaar.

Volgens Bell (1992:30-46) is teorievorming ten opsigte van die term ritueel dikwels sirkulêr van aard. Eerstens word die twee komponente van ritueel teenoor mekaar gestel: doen en dink, handelinge en refleksie. In rituele handeling word gedoen en saam met die uitvoer van die handeling word gedink. Vervolgens word handelinge en denke vir die uitvoerder van die handeling geïntegreer, maar die handeling bly primêr. Laastens word na die beginpunt teruggekeer. Die betekenis van ' $n$ bepaalde ritueel kan nie deur ' $n$ buitestaander ten volle begryp word nie. Dikwels werk die rituele handeling en die teoretiese refleksie daaroor, op mekaar in. Teoreties word die ritueel soms met vooropgestelde idees benader. Dit kan daartoe lei dat die betekenis van die ritueel binne 'n bepaalde tradisie veralgemeen word of dat universele betekenis daaraan toegeken word (Bell 1992:30-46). Die uitvoerder van die ritueel verstaan wat die ritueel vir hom of haar op daardie oomblik beteken. Buitestaanders voeg onwetend en onwillekeurig eie betekenis toe omdat die verwysingsraamwerke van uitvoerder en die buitestaander kan verskil.

'n Ritueel staan nie los van die kultuur waarin dit uitgevoer word nie. Aan die een kant kan rituele ' $n$ bepaalde kultuur versinnebeeld en die identiteit van groepe en individue versterk. Aan die ander kant maak 'n persoon in 'n bepaalde kultuur op 'n bepaalde manier van die rituele gebruik (kyk Menken-Bekius 1998:23). Dat ritueel nie los van die sosiokulturele konteks verstaan kan word nie, kompliseer die saak. In Suid-Afrika met sy groot verskeidenheid kulture en subkulture word die verstaan van rituele besonder kompleks. 'n Teoretiese onderbou ten opsigte van ritueel kan tot beter begrip van die motiewe en beweegredes onderliggend aan 'n spesifieke ritueel bydra. Verder kan dit pastors in die praktyk van hulp wees wanneer hulle in samewerking met pastorante effektiewe rituele vir spesifieke pastorale situasies moet identifiseer.

Die volgende kontekstuele aspekte is van belang wanneer die term ritueel beskryf word (Langer et al. 2006:2): die medium waarin die ritueel uitgevoer word, byvoorbeeld mondelinge tradisies, geskrewe tekste, werklike uitvoering, film of televisie of selfs die internet; die geografiese, ruimtelike, ekologiese, kulturele, godsdienstige, politieke, ekonomiese, sosiale en geslagspesifieke aspekte van die konteks; die groep of gemeenskap waaraan die tradisie waarvan die besondere ritueel 'n deel uitmaak, behoort. Laastens is die historiese band tussen hierdie aspekte van belang om die relasies te kan begryp.

'n Ritueel is nie 'n een-dimensionele saak nie, dit is meervlakkig. Ekstrom en Hecht (2007:242) noem 'n ritueel "n gesofistikeerde verskynsel'. Vervolgens word verskillende beskrywings van die term 'ritueel' ondersoek omdat '... an extended unpacking of them can be an effective way of developing and controlling a novel line of inquiry' (Geertz 1975:90). Die 'novel line of inquiry' wat hierdie ondersoek beoog het, is die toepassingsmoontlikhede van rituele ten opsigte van rousmartpastoraat.

Vir die doel van hierdie ondersoek, wat pastorale berading binne 'n religieuse kader beoog, is Bronislaw Malinowski ([1925] 1948:36) se onderskeid tussen 'magie' en 'religie' ter sake. Magiese praktyke het met die 'hier en nou' te make dus met die praktiese alledaagse probleme. Dit gaan oor die konkrete doel en konteks van die handelinge wat uitgevoer word. In een van sy bekendste werke, Coral gardens and their magic ([1935] 1965) ken Malinowski 'n pragmatiese funksie aan taal toe, aangesien magiese handelinge dikwels met (tower)spreuke gepaard gaan - verbale handelinge wat tot 'n spesifieke konteks behoort.

Magie pas nie in die kader van teologie in nie. Magie is die manier waarop mense 'n direkte invloed op hulle onmiddellike werklikheid probeer uitoefen (kyk Malinowski [1925] 1948). Magie kan meebring dat pastorante wat hulle 
in 'n mities-letterlike fase (kyk Fowler 1995:135-150) van geloofsontwikkeling bevind, kan glo dat hulle handelinge 'n direkte invloed kan uitoefen en 'n verandering aan die werklikheid kan bewerkstellig. 'n Verdere kwessie rakende magie is die gebruik van simbole en die uitvoer van simboliese handelinge wat ander mense regstreeks raak. Indien iemand die foto van 'n persoon vir wie hy of sy kwaad is, verbrand, is dit belangrik om te besluit of dit as ' $n$ rituele magiese daad beskou kan word en of dit blote uitdrukking van emosie was? 'n Ritueel word 'n magiese daad wanneer die persoon wat die ritueel uitvoer die intensie het dat die ander persoon in die empiriese werklikheid beseer sal word of selfs sal sterf (Heimbrock \& Streib 1994:15-59). Indien 'n pastorant so 'n instrumenteel-magies denkwyse openbaar, sal die pastor versigtig met die gebruik van die ritueel in die pastoraat moet omgaan (kyk Menken-Bekius 1998:262-264). Anders as in die geval van magie, gaan rituele oor simboliese handelinge. Dit kan wel vir die uitvoerder 'n magiese betekenis hê, maar die verskil tussen magiese en nie-magiese rituele lê in die perspektief op die werklikheid. Magiese handelinge word uit 'n religieuse perspektief op die werklikheid gebore.

\section{Simbool en ritueel}

Simbole gee inhoud aan rituele. Die aard van simbole en die maniere waarop dit gebruik word, bied dus insig in die aard en invloed van die ritueel. Volgens Kertzer (1988:11) beskik simbole oor die volgende drie belangrike eienskappe:

- Gekondenseerde betekenis: Simbole beskik oor die vermoë om 'n diversiteit betekenisse saam te bind. Verskeie persone kan dieselfde ritueel beoefen, maar dit verskillend beleef. Simbole beliggaam diverse idees en bring dit byeen. Hierdie idees tree ook op die onbewuste vlak met mekaar in wisselwerking sodat dit samehang in die individu se gedagtegang bring.

- Meerduidigheid: 'n Verskeidenheid betekenisse kan aan dieselfde simbool verbind word. Waar kondensering aandui hoe die interaksie tussen betekenisse tot nuwe betekenis lei, dui meerduidigheid aan dat dieselfde simbool deur verskillende mense op verskillende maniere verstaan kan word.

- Dubbelsinnigheid: 'n Simbool het nie een enkele betekenis nie. Die samelewing, tradisie of kultuur kan 'n betekenis, wat deur die meerderheid aanvaar word, daaraan heg. Simbole kan egter ook oerbetekenisse hê. Die krag van simbole lê juis in die kompleksiteit en onsekerheid oor die presiese betekenis daarvan.

Simbole is die boustene van rituele. Rituele bestaan uit simboliese handelinge en simboliese taal. ' $n$ Simbool is ' $n$ teken waarmee verskillende dinge geassosieer kan word - dikwels van emosionele aard. Dit is dinge, handelinge en woorde wat meer as een betekenis kan dra. 'n Ritueel is meerstemmig en roep 'n dieper werklikheid op. Die handeling is (emosioneel) gelade. 'n Simbool oorskry grense. 'n Gesimboliseerde saak is selfverklarend - en het geen uitleg nodig. Lukken (1986:11) stel dit soos volg: "n Simbool is 'n ding, wat sonder dat hy die ding is, tog die ding is.' Die saak self het deel aan 'n dieper werklikheid waarna dit verwys. Iets wat afwesig is, kan teenwoordig gemaak word deur die simbool wat wel aanwesig is. Simbole word nie gemaak of uitgedink nie, dit word gevind. In oorgangsrituele word daar steeds gesoek na die simboliek van die werklikheid waaraan die individu deel wil kry. Simboliese handelinge is dus die kleinste eenheid wat die eienskappe van 'n ritueel dra.

Die manier waarop met 'n simbool omgegaan word, stem ooreen met die manier waarop daar met dit, wat gesimboliseer word, omgegaan sou word. Simbole word gekoester deur die band met die persoon of dit waarvoor dit staan, te bewaar (Nieuwkoop 1986:45-47). 'n Simboliese handeling impliseer dat gedoen word 'asof' die werklikheid is soos wat die individu dit sou wou hê. ' $n$ Simbool beeld iets anders uit omdat dit daarmee geassosieer kan word (Turner 1967:19). 'n Simbool is iets konkreets in die waarneembare werklikheid wat die afstand tussen hierdie werklikheid en die ander onsigbare werklikheid wat gesimboliseer word, oorbrug. Dit word nie bedink word nie, maar intuïtief verstaan. Simboliese waarde kan aan enige saak toegeken word. Dit hang af van die behoeftes van die persone wat aan die ritueel deelneem. Die persone moet die simboliek ken en die doel daarvan verstaan. Die pastor speel 'n sentrale rol in die vorm- en betekenisgewing van simbole in rituele. Wat die pastor as die uiteindelike doel beskou, moet by die verwagting van die pastorant inskakel.

\section{Kenmerke van ritueel}

Rituele kan terselfdertyd meer as een betekenis, doel of effek hê. Dit kan nie te eng as iets godsdienstig of bo-natuurlik beskryf word nie, maar dit kan ook nie te breed as 'n alledaagse menslike handeling beskryf word nie (Ekstrom \& Hecht 2007:242). Vervolgens word 'n wye teoretiese blik op rituele gebied om perspektiewe, wat spesifiek vir die fokus van die ondersoek relevant is, te identifiseer en te beskryf.

\section{Ritueel as sinloos}

Pinxten (1995:597) beskryf rituele as die gestandaardiseerde, stereotiperende gedrag van 'n groep of gemeenskap wat in wese as sinlose aktiwiteite beskou kan word. Staal (1986:42-43) stel dit soos volg: 'Ritual is, like language, a rule governed activity; ... the assumption that rituals express meaning like language is not only inaccurate but misleading.' Hoewel Staal en Pinxten rituele as leeg en betekenisloos beskou, meen hulle tog dat rituele bestudeer behoort te word. Net soos wat taalkundiges die linguïstiese struktuur van 'n ander taal analiseer, so behoort 'n strukturele analise of 'n 'grammatika' vir rituele ontwikkel te word. Rituele kan, net soos taal, slegs los van die boodskappe en inhoud bestudeer word.

\section{Ritueel as magsuitoefening}

Volgens die Franse sosioloog, Pierre Bourdieu (1977, 1990) bring'n ritueel nie werklik geskiedenis en struktuur bymekaar nie. Geskiedenis en struktuur bestaan net vir sover dit deur menslike aktiwiteite in die vorm van kulturele waardes 
herproduseer word. Vir Bourdieu is rituele strategiese praktyke om kultuur te oorskry en aan die behoeftes van die situasie te voldoen. Dit is 'n performatiewe medium vir die onderhandeling van magverhoudings. Maurice Bloch (1989) se ondersoek fokus op die wyse waarop rituele daartoe bydra om gesag, ideologie en mag te konstrueer. In kontras met die meer kognitiewe vorme van kennis in alledaagse praktyke, produseer rituele ideologiese vorme van kennis (Bell 1997:77-79). Vir Bloch (1989:45) is 'n ritueel die uitoefening van 'n spesifieke vorm van mag.

\section{Ritueel as gereguleerde en formele handeling}

In moderne Westerse samelewings word rituele gesien as spesiale aktiwiteite wat verband hou met sakrale tradisies en georganiseerde godsdiens en wat dus inherent van daaglikse roetine verskil. Hierdie assosiasie met tradisie en georganiseerde godsdiens het tot gevolg dat rituele dikwels in 'n moderne en na-moderne wêreld as verouderd beskou word. ' $n$ Kenmerk van rituele is die formaliteit daarvan. Rituele word dikwels as outentieke herhaling van historiese gebeure beskou. ' $n$ Verdere kenmerk van rituele gedrag is 'invariansie': 'n stel handelinge word op 'n gedissiplineerde wyse presies net so herhaal. Vir sommige teoretici is dit die primêre eienskap van rituele gedrag. Die klem kan geplaas word op die versigtige choreografie van handelinge, die selfbeheersing van die beoefenaar, of die ritme van herhaling waardeur die georkestreerde aktiwiteit die verlede met die hede verbind.

Die rituele wat in hierdie ondersoek vir gebruik in die pastoraat oorweeg word, voldoen nie volledig aan die bogenoemde beskrywing nie. Rituele sal soms net een keer uitgevoer word en daar is ook nie sprake van 'n algemene band met tradisie nie. Die rituele sal wel met die persoonlike geskiedenis (in daardie sin dan wel 'n soort 'tradisie') van die persoon self verband hou. Hierdie afwyking van die standaardbeskrywings van 'n ritueel beteken egter nie dat pastorale rituele as onvoldoende afgemaak kan word omdat die rituele nie noodwendig herhalend van aard is nie. Wat van belang is in hierdie soort ritueel, is die band wat tussen die hede en die verlede geskep word. 'n Ritueel word 'n oomblik van herinnering. Volgens Kertzer (1988:8-9) lewer rituele bydrae om die chaos van menslike ervaring, in hierdie ondersoek spesifiek die chaos van die verlieservaring, te orden en binne 'n samehangende raamwerk te plaas.

Om as ritueel te kan kwalifiseer, word verskeie riglyne en spesifikasies vir die uitvoering van die handeling ter sake (Lewis 1980:11). Handelinge wat 'n beroep op bonatuurlike kragte doen, word dikwels as rituele beskou. Rituele onderskei die sakrale wêreld van die profane (Bell 1997:138-159). Dit stel mense in staat om 'n sakrale ervaring te hê wat die profane werklikheid transendeer. Vir Müller (1996:183-186) is rituele simboliese handelinge wat uit woorde en handelinge bestaan. Dit is simbolieskommunikatiewe handelinge wat die mens met 'n dieper realiteit in aanraking bring en so menslike ervaring verryk. Sulke handelinge word dikwels formeel gestruktureer en is religieus van aard. 'n Ritueel is die reaksie of antwoord van 'n individu of gemeenskap op ' $n$ ervaring.

Deur die geskiedenis heen is byna elke menslike aktiwiteit op ' $n$ rituele wyse uitgevoer of het dit deel van 'n ritueel uitgemaak. Sommige handelinge is net inherent anders as ander. Dit kan sekulêr of godsdienstig wees. Sommige aktiwiteite kan op grond van spesifieke kenmerke as 'ritueelagtig' beskryf word. Naas die rituele wat deur tradisie geformaliseer is, kan verskillende aktiwiteite geritualiseer word (Bell 1997:91). Antropoloë het rituele tipies beskryf as kultureel gestandardiseerde, herhalende aktiwiteit, wat hoofsaaklik simbolies van aard is en ten doel het om 'n invloed op menslike sake uit te oefen of om mense toe te laat om hulle plek binne die groter geheel beter te verstaan. Dit sluit betrokkenheid by die bo-natuurlike dimensie in (Kertzer 1988:8-9). Die mees invloedryke sosiaalwetenskaplike perspektief op rituele is dié van Émile Durkheim ([1915] 1965:37-41) wat dit met godsdienstige praktyke in verband gebring het. Rituele is die reëls wat voorskryf hoe mense hulleself in die teenwoordigheid van die sakrale behoort te gedra. Vir Durkheim is die aanbidding van 'n godheid die simboliese wyse waardeur mense hulle eie samelewing vereer. Die 'sakrale' verwys dan nie na die bo-natuurlike nie, maar eerder na mense se emosionele afhanklikheid van mekaar, hulle sosiale bande, asook die gereguleerde ordes in die samelewing.

'n Ritueel bestaan nooit in isolasie nie, dit is ' $\mathrm{n}$ handeling tussen ander, beide sakraal en profaan, wat van generasie tot generasie oorgedra word. Elke ritueel vind binne die konteks van sosiale gebruike, historiese praktyke en daaglikse roetines plaas. Daar is ook unieke faktore aanwesig wat medebepaal hoe die ritueel uitgevoer sal word (kyk Bell 1997:172). Gebruike en werklike situasies is die boumateriaal waaruit spesifieke rituele gekonstrueer word en waarbinne hulle betekenis kry.

\section{Ritueel as performatief}

Teen die middel van die 1970's het die 'performatiewe benadering' tot rituele na vore gekom, byvoorbeeld die dramatisme van Kenneth Burke $(1966,1973)$, Victor Turner $(1969,1982)$ se idee van rituele as sosiale drama, J.L. Austin (1975) se teorie oor performatiewe uitsprake, Erving Goffman $(1959,1967,1972,1974)$ se werk oor rituele eenhede wat die uitoefening van sosiale interaksie struktuur gee en Maurice Bloch (1989) se analise van die gevolge van geformuleerde spraak en sang. Volgens die 'performatiewe benadering' is die verhouding tussen mite en ritueel een van wisselwerking. Volgens kulturaliste is daar 'n estetiese band tussen drama, musiek, volksverhale, dans en ritueel. Die metafore teenwoordig in rituele handelinge verpersoonlik kulturele ideale in die vorm van sosiale houdings en persoonlike ervarings. Rituele dien as performatiewe medium vir sosiale verandering. Rituele vorm mense en mense gee vorm aan rituele. So konstrueer hulle hulle wêreld (Bell 1997:73). Deur rituele druk mense uit hoe hulle hulleself binne die groter geheel verstaan (Bell 2007:4-5). 
'n Ritueel is 'n sosiale handeling wat binne 'n spesifieke kulturele konteks plaasvind. Dit is waar van alle rituele, hetsy sekulêr of religieus, privaat of gemeenskaplik. Rituele behoort dus in terme van die sosiale en kulturele konteks waarvan hulle deel uitmaak verstaan en geïnterpreteer te word. Die term 'ritueel' kan na 'n algemene handeling verwys. Dit kan ook na 'n spesifieke handeling of proses verwys. Rituele sisteme bestaan uit afsonderlike rituele waarvan die vorm, simbole, konseptuele kategorieë en mikpunte met mekaar verband hou. Rituele behels altyd handeling: iets word gedoen of uitgevoer (Gorman 1990:14-20).

Die term 'ritueel' is deur psigoloë soos Freud ([1913] 1946, $1923)$ en Erikson $(1968,1980)$ met die term 'seremonie' in verband gebring om te verwys na die patologies stereotipiese gedrag van sommige senuweelyers en ook na sekere gebruiklike en herhalende interaksies tussen mense. Volgens Turner (1967:95) is rituele transformerend, terwyl seremonie bevestigend is. Rituele geskied volgens 'n patroon en dra simboliese betekenis (Anderson 2010:42). Dit word gewoonlik in ' $n$ spesifieke volgorde uitgevoer en bestaan uit intensionele handelinge wat meestal met ' $n$ spesifieke gebeurtenis of toestand verband hou. Die volgorde is dikwels van besondere belang omdat rituele betroubaar genoeg moet wees om betekenis te organiseer of herorganiseer. Daar is altyd ' $n$ performatiewe aspek aan rituele verbonde.

Rituele is simboliese handelinge wat dit op ' $\mathrm{n}$ min of meer voorgeskrewe wyse moontlik maak om van een fase afskeid te neem en die volgende fase te betree. Rituele speel dus op die drempels van die lewe af. Dit het ten doel om verandering op bewuste en onbewuste vlakke te bring. Die konkrete handelinge dring tot die bewussyn deur en dan kan die boodskap ook die onderbewussyn bereik. So is ' $n$ ritueel die katalisator vir die statusverandering van 'n individu of die strukturele veranderinge in ' $n$ groep. Dit bring nuwe verhoudings tot stand en bevestig dit. Dit is belangrik dat rituele aansluiting vind by die leefwêreld van die individu wat dit uitvoer. As 'n ritueel goed beplan en gekies word, kan dit 'n nuttige hulpmiddel vir die pastoraat word. Daar moet 'n spesifieke plek en tyd aan rituele toegeken word. Die rituele moet by die betrokkenes en hulle ervaring pas (Nieuwkoop 1986:36). Wat by die een individu pas, pas nie noodwendig by 'n volgende nie.

Hoewel rituele dikwels tot 'n reeks ondeurdagte, herhalende gewoontes gereduseer word, is dit nie 'n voldoende beskrywing nie. Dit onderskat die krag en relevansie van rituele vir menswees, ook in die huidige na-moderne tyd. Rituele is eerder intensionele (dus weldeurdagte) handelinge wat werklike verandering kan meebring. Mense voel intuitief aan hoe rituele op die regte manier en gepaste tye uitgevoer behoort te word. Hulle kom dadelik agter wanneer daar fout is. Twee tipes rituele kan onderskei word, naamlik dié wat ten bate van gode of voorvaders uitgevoer word en dié wat ten bate van mense uitgevoer word. Die transformasie wat rituele meebring, is nie kognitief verklaarbaar nie en mense word dikwels daardeur verras. Viviers (2012:5) wys daarop dat rituele mense se verbeelding aangryp en hulle toegang tot hulle intuïsie, emosies, motiverings en verbeelding gee - iets waarin kognisie alleen nie kan slaag nie.

\section{Ritueel as sosiale legitimering}

Deur rituele word erkenning aan 'n gebeurtenis in mense se lewens gegee. Volgens Smith (1987:103) is 'n ritueel 'n manier om aandag te gee en belange aan te dui. Verlies wat nie deur die sosiale groep erken en gelegitimeer word nie, word moeiliker verwerk. Rituele kan daartoe bydra om patrone wat nie meer werkbaar is nie, te ontbind sodat iets nuut gebore kan word. Die genesende krag (vir gelowiges 'van God') kan ervaar word wanneer rituele erkenning aan die realiteit van pynlike herinneringe gee en aanleiding gee tot die vorming van nuwe gedragspatrone wanneer die ritueel verby is.

Rituele is geordende, opeenvolgende of gestileerde sosiale gedrag wat oor bewusmakende eienskappe beskik. Vir die gehoor is dit 'n besondere gebeurtenis wat op 'n spesiale plek en/of tyd vir 'n spesiale geleentheid en/of boodskap uitgevoer word (Klingbeil 2007:18). 'n Baken (of merker) is 'n teken wat betekenis aan iets verleen. Bakens definieer sosiale omgang en diskoerse. Dit maak mense bewus van wat gebeur en van wat die gepaste optrede in daardie omstandighede sou wees. Rituele is bakens wat uit handelinge bestaan soms eenvoudige handelinge en soms veel meer komplekser (Ter Borg 2008:40-41). Dit kan godsdienstig van aard wees, maar nie noodwendig nie. Rituele sluit soms die groep of gemeenskap in en soms is dit ' $n$ individuele ervaring.

Tom Driver (1991:71) onderskei tussen 'shelter' rituele en 'pathway' rituele. Eersgenoemde is rituele wat mense ten tye van moeilikheid of verandering ondersteun. Dit beklemtoon die kontinuiteit van die lewe en help om van een status na 'n volgende te beweeg. Dit kan vergelyk word met wat Van Gennep ([1960] 1965) as 'oorgangsrituele' beskryf, veral dié wat in die post-liminale tydperk plaasvind. Hierdie rituele bou ' $n$ pad vanuit die liminale terug na die werklikheid en vergemaklik die oorgang wat besonder pynlik of selfs onsigbaar sou kon wees. Begrafnisse dien as voorbeeld hiervan. Elke ritueel verteenwoordig in 'n sekere sin die afskeid van ' $n$ vorige toestand en die oorgang na 'n nuwe toestand - dus oorgangsrituele.

\section{Ritueel as herhalende handeling}

Rituele behoort nie tot die sakrale beperk te word nie (kyk Goffman 1972; Moore \& Myerhoff 1977). Dit sou 'n té eensydige siening van 'n ritueel wees. Beide godsdienstige en sekulêre rituele vorm deel van hoe mense betekenis aan hulle werklikheid gee. Rituele behoort vir die mense wat daaraan deelneem ruimte te laat om inhoud en betekenis daaraan toe te voeg. Die vorm van die handeling kan voorgeskryf en formeel wees of meer spontaan. Rituele kan denke en handeling bymekaar bring. In Westerse denke bestaan daar dikwels 'n dichotomie tussen doen en dink (vgl. MenkenBekius 1998:19-20). Dit lei tot verarming. Rituele oorkom die 
dichotomie: handelinge gaan met denke gepaard. Hoewel die twee pole van mekaar onderskei kan word, kan hulle nie geskei word nie. Tellini (1987) stel dit soos volg:

Even in its simplest form, a rite is composed of word and gesture. Words alone fail to engage the dimension of the body and may therefore lack the power to convince ... together, word and gesture may become not only a skillful instrument of communication but also a moment of disclosure. (bl. 241)

Soms vind rituele handelinge gereeld plaas. Soms gebeur 'n ritueel net een keer-'n unieke geleentheid wat vir'n spesifieke groep mense geskep is. Dit is nie noodwendig herhalend of stereotipies nie, kan kreatief wees en selfs 'n speelse element bevat (Berry 2009:95). Elke akademiese dissipline wat daarmee werk, het ' $n$ eie invalshoek ten opsigte van ' $n$ ritueel. Volgens die praktiese teoloog en pastoraatkundige, Corja Menken-Bekius (2001:29), sou die betekenis van ritueel eerder in speelsheid voor God se aangesig of in die reik na 'n transendente waarheid gesoek moet word.

\section{Ritueel en rousmartpastoraat}

Uit die breë perspektiewe wat die ritueelteorieë uit verskillende dissiplines bied, selekteer ek vervolgens aspekte wat vir die gebruik van ritueel in die pastoraat van belang is en dan spesifiek vir die fokus van hierdie studie, naamlik rousmartpastoraat.

\section{Spesiale tyd of plek versus gewone tyd of plek}

'n Ritueel is 'anders'. Dit vind buite die gewone roetine van die lewe plaas en spesiale tyd word daarvoor ingeruim. Tydens die rouverwerkingsproses word dit vir die deelnemers duidelik gemaak dat die ritueel met ' $n$ bepaalde spesiale doel uitgevoer word. Hierdie ritueel hoef nie noodwendig godsdienstig van aard te wees nie.

\section{Ritueel en die narratief van verlies}

Rituele word altyd deur 'n verhaal voorafgegaan, 'n narratief wat die rede en doel vir die ritueel bied. In hierdie geval volg die ritueel op ' $n$ verhaal van verlies. Die mense wat rou, is nie toeskouers nie, hulle neem aan die handelinge van die ritueel deel. Dit geskied intensioneel.

\section{Ritueel kanaliseer ervaring en ritueel as simboliese handeling}

Rituele bied ' $n$ kanaal om iets wat nie eintlik in woorde uitgedruk kan word nie, uit te druk. Simbole is die boublokke van rituele en daarom sal elke handeling (die woorde en handelinge) simboliese waarde dra. 'n Geïntegreerde benadering is nodig, want rituele betrek die liggaam én denke, is aktief én intensioneel.

\section{Ritueel fasiliteer verandering}

Van Gennep ([1960] 1965) se drie fases van oorgangsrituele, naamlik afskeidsrituele, oorgangsrituele en inlywingsrituele is spesifiek van toepassing in verliessituasies. Die samelewing se fokus is op die ritueel van afskeid, die begrafnis. Die mense wat rou, word deur die groep of gemeenskap ondersteun. Die ander twee fases, naamlik oorgang en veral inlywing, vra egter ook sosiale ondersteuning. Wanneer hierdie twee fases in die rouproses aanbreek, het die groep of gemeenskap meestal reeds by die verlies verby beweeg en die persoon wat die verlies gely het, staan dikwels alleen. Hierdie ondersoek toon dat persone ook gedurende die oorgangs- en inlywingsfases begelei en ondersteun behoort te word. Daarom behoort die groep of gemeenskap oor hulle noodsaaklike rol in hierdie proses ingelig te wees.

\section{Ritueel legitimeer}

Rituele skep spesiale geleenthede om te onthou, herdenk en vier. Rituele plaas deur die proses van rou bakens langs die pad van herstel. Openbare erkenning van die verlies en die legitimiteit daarvan word aan die naasbestaandes bevestig. In die geval van miskrame of stilgeboortes word die verliese wat gely word die minste erken. Die gesin moet erkenning ontvang dat hulle ' $n$ nuwe familielid verloor het en dat hulle deur 'n rouproses gaan. Daar behoort ruimte in die gesin se narratief geskep te word sodat die oorlede baba deel van die gesinsverhaal kan vorm.

\section{Ritueel as sosiaal of privaat}

Rituele hoef nie altyd sosiaal of gemeenskaplik van aard te wees nie. Individue kan hulle eie rituele bedink en uitvoer. ' $n$ Ritueel is inherent kreatief en daarom bruikbaar om nuwe werklikhede, denke en identiteit te vestig.

\section{Ritueel is kreatief}

Rituele is oop vir interpretasie. Indien die ritueel onder die begeleiding van 'n pastor plaasvind, kan die intensie en doel van rituele in die beplanning ingesluit word. Hoewel mense se interpretasie van wat hulle ervaar, nie voorgeskryf kan word nie, sal dit goed wees om die bedoeling van die handelinge vooraf te bespreek en te verduidelik. Die ritueel moet by die emosies en verbeelding van die pastorant inpas.

\section{Uitgangspunte vir die gebruik van ritueel in rousmartpastoraat}

In die bespreking van ritueelteorieë is insigte geïdentifiseer wat toepasbaar is en bruikbaar gemaak kan word vir pastoraat tydens die rouproses. Die insigte van die antropoloog, Rappaport (1999:32-46), die psigoloog, Onno Van der Hart (1983:5-6), die praktiese teoloog wat op breinnavorsing fokus, David Hogue (2003:122-143), en die pastoraatkundige, Corja Menken-Bekius (1998:26-35) word vervolgens geïntegreer om as uitgangspunt te dien vir die gebruik van rituele in die pastorale versorging van mense wat 'n verlies gely het.

Rituele handel dikwels oor 'n seremonie wat van gemeenskaplike belang is. Daar is geen intrinsieke of universele verstaan van wat 'n ritueel konstitueer nie (Bell 1997:164). Vanuit die veld van die antropologie identifiseer 
Rappaport (1999:32-46) vyf kenmerke van rituele: enkodering deur ander, vormlikheid, invariansie, uitvoering en formaliteit versus fisiese effektiwiteit. Onno van der Hart (1983) beskryf rituele as:

Voorgeskrewe, simboliese handelinge wat op 'n sekere manier en in 'n sekere volgorde uitgevoer moet word en moontlik deur verbale formules vergesel kan word. Naas die formele aspekte kan daar 'n ervaringsaspek by rituele onderskei word. (bl. 5-6)

Rituele vereis intensiewe betrokkenheid. As dit nie die geval is nie, word daar na leë rituele verwys. Sommige rituele word herhaaldelik deur dié wat daarby belang het, uitgevoer. Ander, word slegs een keer uitgevoer. Van der Hart (1983) beklemtoon vier dimensies, naamlik voorskrif, simbool, uitvoering en herhaling. Hogue (2003:123) voeg drie kenmerke by: die publieke aard daarvan, die effektiwiteit daarvan en die feit dat dit 'n spesiale doel voor oë het. Menken-Bekius (1998) som dit soos volg op:

Rituele is vanselfsprekende, eenmalige of herhaalde, meestal simboliese handelinge, dikwels vergesel deur toepaslike formules en tekste, waardeur die individu liggaamlik en interaktief betrokke kan raak by 'n werklikheid wat deur die ritueel verteenwoordig word. (bl. 26)

Die ooreenkomste tussen hierdie vier eksponente van ritueelstudies word vervolgens bespreek

\section{Vormlikheid en herhaling}

Rappaport se vormlikheid en invariansie en Van der Hart, Hogue en Menken-Bekius se element van herhaling kan saam gegroepeer word. Rituele word aan hulle vorm herken. Reekse rituele bestaan uit konvensionele elemente. Hoe die elemente gerangskik word, asook die gebare en liggaamshoudings, is vooraf bepaal. Rituele word in 'n spesifieke konteks uitgevoer en word op vasgestelde tye herhaal. Dikwels geskied dit ook op 'n spesiale plek. Herhaling skep die gemaklikheid van bekendheid (Hogue 2003:135). Mense raak bekend met 'n ritueel en die herhaling skep 'n gevoel van geborgenheid, dit bevestig die idee dat sommige dinge dieselfde kan bly. Tog is daar ruimte vir doelbewuste variasie in ritueel.

Herhaling is nie noodsaaklik nie. Dit is opsioneel. Eenmalige rituele het 'n sterk simboliese inhoud en sluit by 'n spesifieke en unieke situasie aan. Selfs in eenmalige rituele word dikwels bekende elemente gebruik, maar net op 'n nuwe wyse. Menken-Bekius (1998:27) is van mening dat 'herhaling' nie beskou kan word as 'n normatiewe kriterium vir die beskrywing van watter handelinge ritueel is en watter nie.

\section{Interaktief}

Die mens se liggaam is aktief by rituele handeling betrokke: daar word geloop, gestaan, gesit, gelê, gekniel, gevas, gedrink of geëet. Die oë kan gesluit word. Daar kan gesing word, tekste kan voorgedra word, daar kan gefluister of geskreeu, gelag of gehuil word. Daar kan geluister, gepraat of vertel word. Voorwerpe kan aangeraak, oopgemaak, gesluit, gebrand, gebreek, rondgedra, begrawe of uitgedeel word. Hande kan gevou, geskud, gebal of gewas word. Daar kan gesoen of omhels word. Die reuksintuig word betrek. Liggaamlike betrokkenheid is onlosmaaklik deel van ritueel. Hoe hoër die simboliese lading van 'n ritueel, hoe meer betekenis sal daar wees en hoe dieper sal die interpretasie gaan. Nie alleen is die inhoud van die boodskap van belang nie, maar ook wie die stuurder en ontvanger is en in watter verhouding hulle tot mekaar staan. Beide Menken-Bekius (1998:32-33) en Hogue beskou die publieke element as 'n kenmerk van 'n ritueel. As daar geen performatiewe element sou wees nie, is daar geen sprake van ritueel nie.

Die krag van woorde is beperk. Daarom word in rousmartbegeleiding ondersoek ingestel na'n manier waarop mense hulle verhale tot uitdrukking kan bring wat nie tot woorde beperk is nie. Dit beteken nie dat woorde uitgeskakel word nie, maar eerder dat woorde op 'n kreatiewe wyse gebruik word en dat simboliek help om die verhaal te interpreteer. Torevell (2000:24) wys daarop dat ritueel sowel iets sê as doen. Die gehoor ervaar dit en gee betekenis daaraan.

\section{Ritueel as voorgeskrewe of beplande handelinge}

Hoewel rituele meestal gevestigde gebruike volg, laat Hogue ruimte daarvoor dat nuwe rituele vir spesifieke doeleindes ontwerp kan word. Dit verg noukeurige beplanning. Rappaport se 'enkodering deur ander' noem Hogue (2003:124-126) 'voorskrif' en Menken-Bekius (1998:26) 'vanselfsprekendheid'. Individue voer handelinge uit wat hulle verstaan en wat in hulle situasie en konteks voortkom. Die handeling het betekenis en waarde vir die uitvoerder. Sulke handelinge word nie bedink of beredeneer nie. Dit is die vanselfsprekende handeling vir ' $n$ spesifieke situasie, omdat dit nog altyd as gepas beskou is. Tennekes (1982:90) meen dat rituele wat op gewoontes en etiket geskoei is, 'n verskuilde normatiewe komponent bevat. Dit is uitdrukking van 'hoe dinge behoort wees'.

'Voorskrif' verwys na riglyne vir die uitvoer van 'n ritueel. 'n Ritueel wérk omdat dit beplan is. Die beplanning kan algemeen of spesifiek van aard wees. Wanneer die beplanning slegs ' $n$ riglyn is, is daar ruimte vir soepelheid. Rituele kan aan die een kant vir mense ruimte skep om iets van hulleself uit te druk, maar aan die ander kant kan dit ook presisie en eenvormigheid beklemtoon. Die 'plan' van sommige rituele het ' $n$ lang geskiedenis, ander nie. ' $n$ Familie kan byvoorbeeld 'n ritueel vir 'n gebeurtenis, wat slegs een keer gaan plaasvind, beplan.

Rituele wat self ontdek of geskep word, kan uiters effektief wees. 'n Persoon se eie rituele dra die betekenis van hulle geskiedenis. Die beplanning van 'n ritueel kan deur dié wat deelneem gedoen word, iemand anders kan dit namens die deelnemers doen, of dit kan van vorige generasies oorgedra word. Die voorbereiding sluit in om gereed te maak om aan die ritueel deel te neem. Kontemplasie is belangrike voorbereiding, want dit verplaas die persoon na 'n sakrale ruimte. Daar moet voorberei word voordat daar deelgeneem kan word. 
Saam met voorbereiding kom afwagting. Omdat rituele tyd en plek as besonders afsonder, fokus dit die aandag op dit wat gaan gebeur en die betekenis daarvan. Die afwagting is nie altyd positief nie, want rituele vind nie slegs by vreugdevolle geleenthede plaas nie. Selfs die mees vreugdevolle gebeure kan ' $n$ mate van pyn bevat. So kan verdrietige seremonies soos 'n begrafnis gevoelens van dankbaarheid oproep. 'n Ritueel bied 'n 'houer' vir gemengde gevoelens. Dit skep 'n veilige ruimte vir die ervaar van teenstrydige gevoelens. Hierdie verskerpte fokus op die gebare, gevoelens en gedagtes is kenmerkend van rituele en kan toegang tot die diepste teenstrydighede en dubbelsinnighede wat in die lewe ervaar kan word, verleen.

Net soos mense reëlings vir groot gebeurtenisse in die lewe tref, behoort die beplanning van die rituele van afskeid, oorgang en inlywing (Van Gennep [1960] 1965) ook aandag te geniet. Dit is belangrike oomblikke wat in die individu se lewe sal uitstaan en wat vormend ten opsigte van nuwe gedragspatrone, denkwyses en aanpassing by 'n nuwe identiteit kan wees. 'n Ritueel kan lewensveranderend wees (Hogue 2003:125). Rituele kan nie halfhartig benader word nie, omdat dit dan waardeloos is en selfs meer skade as goed kan inhou.

\section{Simboliese betekenis van ritueel}

Simbole kan nie apart van hulle konteks geïnterpreteer word nie. Die waarde van 'n simbool lê in dit waarna die simbool verwys. Alle simbole is tekens, maar nie alle tekens is simbole nie. In rituele kan beide tekens en simbole onderskei word. Die betekenis van tekens is eenduidig. Daarteenoor het simbole altyd meerduidige betekenis. Komplekse betekenisse kan in een simbool of simboliese handeling saamgevoeg word (Menken-Bekius 1998:28-31). Wanneer verskillende sake of emosies tegelyk uitgedruk moet word, is die gebruik van simbool die aangewese weg om te volg.

Verskillende mense vind verskillende betekenisse in dieselfde ritueel. Deelnemers ontdek verskillende vlakke van betekenis in die ritueel. Die simboliese betekenis verander soos die behoeftes van die oomblik verander. Wanneer die betekenis van simbole beperk word, verloor die simbole hulle krag. Simboliese handelinge en objekte kommunikeer meer as wat woorde kan doen. Simboliese rituele transendeer hulleself. Die volle betekenis en krag van rituele word nooit ten volle deur die handelinge of objekte van die ritueel weerspieël nie. Hulle is slegs kanale tot 'n dieper verstaan van onsigbare of geestelike werklikhede (Hogue 2003:130-132). Mense leef in hulle konkrete liggame in 'n wêreld van konkrete dinge wat deur die sintuie ervaar word. Tog kan tasbare, sigbare objekte ' $n$ verband skep tussen die objek en die geestelike en onsienlike realiteite waarvan mense nie altyd bewus is nie.

\section{Effektiwiteit}

Vormlikheid en formaliteit veronderstel dat daar nie van die vorm of die gereelde herhaling van die ritueel afgewyk sal word nie. Die term 'formeel' kan egter ook in kontras tot 'funksionaliteit' oftewel 'effektiwiteit' gebruik word. Rituele handelinge produseer nie ' $n$ tasbare resultaat in die fisiese, uiterlike leefwêreld nie. Juis hierdie gebrek aan materiële effektiwiteit is 'n kenmerkende eienskap van 'n ritueel. Soms vestig rituele die aandag slegs op 'n spesifieke gebeurtenis en het rituele ten doel om herinnering te koester. Ander gebeure kan weer nie sonder rituele plaasvind nie, soos byvoorbeeld 'n lewensoorgang. Wanneer rituele werklik effektief is, vind verandering in uitvoerproses van die ritueel plaas. Rituele funksioneer dikwels op maniere wat nie rasioneel geantisipeer sou kon word nie (Viviers 2012:1). Barrett (2004:126) noem rituele gebeurtenisse waar iets of iemand beïnvloed word deur die handelinge van 'n agent wat iets wat nie van nature uit die handeling sou voortvloei nie, tot stand bring.

\section{Ritueel as uitsonderlike geleentheid}

Sommige rituele word vir 'n spesifieke situasie en doel geskep en uitgevoer. Daar is byvoorbeeld nie pasklaar sosiale gebruike vir hoe om verliese soos die werklikheid van infertiliteit, miskrame, kinders wat die huis verlaat of bejaardes wat uit die groot familiehuis verhuis, te ritualiseer nie. Rituele sou kon bydra om die realiteit van die oomblik 'n naam te gee, dit as realiteit te erken en 'n aanduiding van die rigting vorentoe te gee.

Die betrokkenheid van die gemeenskap kan tot die waarde van rituele bydra. Indien mense wat werklik omgee as getuies optree, word die krag van die ritueel vergroot omdat getuies 'n legitimiteit daaraan verleen. Pastoraat het deur die loop van die vorige eeu verbreed om nie net meer op individue te fokus nie, maar om ook families, die gemeenskap en die samelewing in te sluit. Wanneer die gemeenskap erkenning aan 'n gebeurtenis verleen, aanvaar hulle medeverantwoordelikheid.

\section{Ritueel as versimboliseerde werklikheid}

Daar kan tussen simboliese en konkrete werklikhede onderskei word (kyk Berger \& Luckmann 1967). Simbole verwys na iets wat nie empiries voorhande is nie, terwyl 'n konkrete werklikheid empiries van aard is. Daar is ook werklikhede wat slegs versimboliseer kan word, wat net in die verbeelding en die fantasie bestaan. Rituele fokus op 'n ander soort werklikheid en bied 'n uitdrukkingsvorm vir iets wat nie feitelik uitgedruk kan word nie. In godsdienstige rituele word ' $n$ transendente werklikheid veronderstel. Hierdie werklikheid word deur die ritueel opgeroep en as 'n teenwoordige (werklike) werklikheid beleef. Daar is 'n dubbele beweging in rituele handeling - die deelnemer reik na ' $n$ bepaalde werklikheid uit en hierdie werklikheid beweeg deur die simboliese uitdrukking daarvan nader aan die deelnemer. Die betekenis van 'n bepaalde ritueel hang saam met die werklikheid waarop hierdie ritueel gefokus is.

\section{Kritiese refleksie op benaderings en modelle}

Vervolgens word die perspektiewe van Rappaport, Van der Hart, Hogue en Menken-Bekius geïntegreer en krities bespreek. 
Voorskriftelikheid/vormlikheid het te doen met die stiptelike beplanning en uitvoering van die ritueel en is belangrik vir effektiwiteit daarvan. Die herhaling van dieselfde ritueel verhoog nie noodwendig die effektiwiteit daarvan in die konteks van rousmartberading nie. Dit hang van die routake of die oorgang wat vir die persoon voorhande is, af. Ek is dit eens met Menken-Bekius dat rituele, veral in die pastoraat, nie werklik op die element van herhaling steun nie. Sulke rituele het nie noodwendig 'n voorgeskrewe vorm of formele elemente nodig nie. Dit hoef ook nie spesifiek 'n godsdienstige ritueel te wees nie.

Rituele is simbolies van aard en dra simboliese waarde. Hogue wys op die publieke aard van rituele. Dit beteken nie noodwendig dat die groep of gemeenskap by die ritueel betrokke moet wees nie. Tog kan hulle'n ondersteunende rol in die bedroefde se lewe speel. Hogue (2003:129-130) meen dat die eintlike werk plaasvind in wat Van Gennep ([1960] 1965) die fases van skeiding en inlywing noem, dus in die fase van oorgang. Dit is die tyd wanneer reëls en verwagtinge anders is. Die gewone vereistes en verwagtings van die samelewing word opgeskort en 'n nuwe manier van kyk na die verhoudings met die self, ander en God word moontlik.

Die inlywingsfase duur langer en daar is soms ' $\mathrm{n}$ heen-enweer beweging, terug na die manier hoe dinge altyd was, alhoewel dinge nooit weer dieselfde sal wees nie. Inlywing vra 'n bewuste terugkeer na die alledaagse lewe. Vir die 'terugkeer' moet daar net so deeglik as vir die afskeidsfase voorberei word. Rituele van inlywing word dikwels agterweë gelaat. Die ondersteuningsisteme behoort opgevoed te word om by die inlywingsrituele wat soms 'n leeftyd kan duur, betrokke te wees. Die intensiteit van die behoefte neem egter wel meesal met die verloop van tyd af. Die individu behoort nie van die groep of gemeenskap vir die uitvoer van die ritueel afhanklik te wees nie. Daar kan ook eie private rituele wees wat 'n persoon na behoefte kan uitvoer. Een van die belangrikste eienskappe van effektiewe rituele is herinnering. Tydens herinnering, leef mense hulle in 'n ander werklikheid in, een wat nie meer hier en nou bestaan nie.

Vir suksesvolle oorgange oor die verskillende drempels van die lewe is dit nodig dat die nuwe fase of tydperk ingegaan sal word, nie van die verlede afgesny nie, maar op die verlede voortgebou sal word. Iemand wat 'n geliefde aan die dood afgestaan het hoef dus nie te vrees dat 'aanbeweeg' beteken dat hulle die oorledene moet vergeet nie. Hulle moet hom of haar eerder op 'n nuwe manier in hulle lewensnarratief inkorporeer. Rituele is hier as 'n tipe 'terapie van onthou' behulpsaam. Die emosionele energie wat in die verhouding met die oorledene belê is, word verskuif en nou in 'n reik na 'n nuwe toekoms waarin die oorledene se herinnering sal bly voortleef, belê. In hierdie toekoms kan die oorlewende weer met die lewe aangaan sonder dat die pad deur rou versper word. Ten spyte van die oorweldigende hartseer as gevolg van die verlies, kan die oorledene steeds op 'n aanvaarbare wyse deel van sy of haar lewensverhaal wees.

\section{Die waarde van ritueel vir rousmartpastoraat}

Rituele bied kanale vir die vloei van die oorweldigende emosies wat dikwels tydens die rouproses ervaar word. Dit kan die rouproses fasiliteer en bevorder - iets wat pynlik, oorweldigend en skrikwekkend kan wees vir die persoon wat rou, is nogtans noodsaaklik vir 'n suksesvolle en gesonde beweeg deur die rouproses. Rituele is besonder gepas omdat dit beide gedagtes en emosies betrek en daarom alle aspekte van menswees aanspreek. Dit bied 'n kognitief-emosionele benadering en kan baie meer vrugte afwerp as wat in die geval van streng kognitiewe benadering moontlik is. Omdat rituele simbolies gelaai is en aktiewe deelname vereis, het dit die vermoë om verder as die strekking van woorde te reik. Wanneer 'n persoon wat rou besluit om die verlies aktief te hanteer, is dit waarskynliker dat 'n gewenste toekoms vinniger en effektiewer bereik sal word as wat andersins die geval sou wees.

\section{Erkenning Mededingende belange}

Die outeur verklaar dat sy geen finansiële of persoonlike verbintenis het met enige party wat haar nadelig kon beïnvloed in die skryf van hierdie artikel nie

\section{Outeursbydrae}

Hierdie artikel is gebaseer op die navorsing van S.B-S. (Universiteit van Pretoria) onder die toesig die toesig van Y.D. (Universiteit van Pretoria).

\section{Literatuurverwysings}

Anderson, H., 2010, 'How rituals heal,' Word \& World 30(1), 41-50.

Austin, J.L., 1975, How to do things with words, 2nd edn., Harvard University Press, Cambridge, MA. http://dx.doi.org/10.1093/acprof:oso/9780198245537.001.0001

Barrett, J.L., 2004, Cognitive science of religion series: Why would anyone believe in God? AltaMira Press, Walnut Creek, CA.

Bell, C., 1992, Ritual theory, ritual practice, Oxford University Press, New York, NY. Bell, C., 1997, Ritual: Perspectives and dimensions, Oxford University Press, New York, NY.

Bell, C. (ed.), 2007, Teaching ritual, Oxford University Press, New York, NY. http:// dx.doi.org/10.1093/acprof:oso/9780195176452.001.0001

Berger, P.L. \& Luckmann, T., 1967, The sacred canopy: Elements of a sociological theory of religion, Doubleday, Garden City, New York, NY.

Berry, J., 2009, 'Changing lives, changing rites: Women creating rituals of transition,' Practical Theology 2(1), 93-102.

Bloch, M., 1989, Ritual, history and power: Selected papers in Anthropology, Athlone Press, London.

Bourdieu, P., 1977, Outline of a theory of practice, transl. R. Nice, Cambridge University Press, Cambridge. http://dx.doi.org/10.1017/CBO9780511812507

Bourdieu, P., 1990, The logic of practice, transl. R. Nice, Stanford University Press, Stanford, CA.

Burke, K., 1966, Language as symbolic action, University of California Press, Berkeley, CA.

Burke, K., 1973, The philosophy of literary form, 3rd edn., University of California Press Berkeley, CA.

Crossley, N., 2004, 'Ritual, body technique, and (inter)subjectivity', in K. Schilbrack (ed.), Thinking through rituals: Philosophical perspectives, pp. 31-51, Routledge, New York, NY.

Driver, T.F., 1991, The magic of ritual: Our need for liberating rites that transform our lives and our communities, Harper Collins, New York, NY.

Durkheim, E., [1915] 1965, The elementary forms of the religious life, transl. J. Swain, Free Press, New York, NY. 
Ekstrom, L. \& Hecht, R.D., 2007, 'Ritual performance and ritual practice: Teaching the multiple forms and dimensions of ritual', in C. Bell (ed.), n.p., Teaching ritual, Oxford University Press, New York, NY. http://dx.doi.org/10.1093/acprof: ritual, Oxford University Press,
oso/9780195176452.003.0019

Erikson, E.H., 1968, 'The development of ritualization', in D.R. Cutler (ed.), The religious situation, pp. 711-733, Beacon, Boston.

Erikson, E.H., 1980, Identity and the life cycle, Norton, New York, NY.

Fowler, J., 1995, Stages of faith: The psychology of human development and the quest for meaning, new edn., Harper Collins, New York, NY.

Freud, S., [1913] 1946, Totem and taboo, transl. A.A. Brill, Vintage Books, New York, NY. Freud, S., 1923, The ego and the id, W.W. Norton \& Company, New York, NY.

Geertz, C., 1975, The interpretation of cultures, Hutchinson, London.

Goffman, E., 1959, The presentation of self in everyday life, Doubleday, New York, NY. Goffman, E., 1967, Interaction ritual, Doubleday, New York, NY.

Goffman, E., 1972, Interaction ritual: Essays on face-to-face behaviour, Penguin Books, Harmondsworth, London.

Goffman, E., 1974, Frame analysis: An essay on the organization of experience, Harper and Row, New York, NY.

Gorman, F.H., 1990, The ideology of ritual: Space, time and status in the priestly theology, Sheffield Academic Press, Sheffield.

Heimbrock, H.G. \& Streib, H., 1999, Magie, Kok Pharos, Kampen.

Hogue, D.A., 2003, Remembering the future, imagining the past: Story, ritual and the human brain, Wipf \& Stock, Eugene, OR.

Kertzer, D.I., 1988, Ritual, power and politics, Yale University Press, New Haven, CT. Klingbeil, G.A., 2007, Bridging the gap: Ritual and ritual texts in the Bible, Eisenbrauns, Warsaw, IN.

Langer, R., Lüddeckens, D., Radde, K. \& Snoek, J.A.M., 2006, 'Transfer of ritual,' Journal of Ritual Studies 20(1), 1-10.

Leach, E.R., 1968, 'Ritual,' in D.L. Sills (ed.), The international encyclopedia of social sciences, MacMillan and Free Press, New York, vol. 13, pp. 520-526.

Lewis, G., 1980, Day of shining red: An essay on understanding ritual, Cambridge University Press, Cambridge. http://dx.doi.org/10.1017/СBO9780511558061

Lukken, G., 1986, De onvervangbare weg van de liturgie, Gooi en Sticht, Hilversum.

Malinowski, B., [1925] 1948, Magic, Science and Religion and other essays, Free Press, Glencoe, IL.

Malinowski, B., [1935] 1965, Coral gardens and their magic, Indiana University Press, Bloomington, IN.

Menken-Bekius, C.J., 1998, Rituelen in het individuele pastoraat: Een praktischteologisch onderzoek, Kok, Kampen.

Menken-Bekius, C.J., 2001, Werken met rituelen in het pastoraat, Kok, Kampen.

Menken-Bekius, C.J. \& Van der Meulen, H., 2007, Reflecteren kun je leren: Basisboek voor pastoraat en geestelijke verzorging, Kok, Kampen.

Moore, S.F. \& Myerhoff, B.G. (eds.), 1977, Secular ritual, Van Gorcum, Assen.

Müller, J.C., 1996, Om tot verhaal te kom: Pastorale gesinsterapie, RGN Uitgewery Pretoria.
Nieuwkoop, R., 1986, De drempel over: Het gebruik van (overgangs)rituelene in het pastoraat, JN Voorhoeve, Den Haag.

Platvoet, J.G., 1995, 'Ritual in plural and pluralist societies: Instruments for analysis', in J.G. Platvoet \& K. van der Toorn (eds.), pp. 25-51, Pluralism and identity: Studies in ritual behaviour, Brill, Leiden.

Pinxten, R., 1995, 'Overgawe om niet: Over riten en sacrale drama's. Interview: Ignace D'hert en Jos Vandikkelen.' Weg van de wêreld: Symbolen en riten, Themanummer van Tijdschrift voor Geestelijk Leven 51, 597-606.

Rappaport, R.A., [1968] 1980, Pigs for the ancestors, 2nd edn., Yale University Press, New Haven, CT.

Rappaport, R.A., 1999, Ritual and religion in the making of humanity, Cambridge University Press, Cambridge. http://dx.doi.org/10.1017/CBO9780511814686

Schoonees, P.C., Swanepoel, C.J., Du Toit, S.J. \& Booysen, C.M. (reds.), 1972, HAT: Verklarende handwoordeboek van die Afrikaanse taal, Voortrekkerpers, Johannesburg.

Smith, J.Z., 1987, To take place: Toward theory in ritual, University of Chicago Press, Chicago, IL. (Chicago Studies in the History of Judaism).

Sørensen, J., 2007, 'Acts that work: A cognitive approach to ritual agency,' Method and Theory in the Study of Religion 19(3/4), 281-300.

Staal, F., 1986, 'The sound of religion', Numen 33(33/64), 185-224.

Tellini, G., 1987, 'Rites and Ritual', in A.V. Campbel (ed.), A dictionary of pastoral care, SPCK, London, p. 241.

Tennekes, J., 1982, Symbolen en hun boodschap: Inleiding in de symbolische anthropologie, Van Gorcum, Assen.

Ter Borg, M.B., 2008, 'Some ideas about the persistence of rituals,' Implicit Religion 11(1), 39-49.

Torevell, D., 2000, Losing the sacred: Ritual, modernity and liturgical reform, T\&T Clark, Edinburgh.

Turner, V.W., 1967, The forest of symbols: Aspects of Ndembu ritual, Cornell University Press, New York, NY.

Turner, V.W., 1969, The ritual process: Structure and anti-structure, Cornell University Press, New York, NY.

Turner, V.W., 1982, From ritual to theatre: The human seriousness of play, Performing Arts Journal Publications, New York, NY.

Van Gennep, A., [1960] 1965, The rites of passage, Routledge, London.

Van der Hart, O., 1983, Rituals in psychotherapy: Transition and continuit, Irvington Publishers, New York, NY.

Van der Hart, O., 1990, Rituelen in psychotherapie: Overgang en bestendiging, 2 de herziene druk, Van Loghum Slaterus, Deventer.

Van Strien, P.J., 1986, Praktijk als wetenschap: Methodologie van het sociaalwetenschaplijk handelen. Van Gorcum, Assen/Maastricht.

Viviers, H., 2012, 'What is the importance of executing rituals 'correctly' and why do people continue to engage in them?', HTS Teologiese Studies/Theological Studies 68(1), Art. \#978, 10 pages. http://dx.doi.org/10.4102/hts.v68i1.978

Zuesse, E.M., 1987, 'Ritual', in M. Eliade (ed.), The encyclopedia of religion, vol. 12, MacMillan and Free Press, New York, NY, vol. 12, p. 405 